\title{
Embedding Content and Language Integrated Learning (CLIL) into English for specific purposes curriculum for vocational high school
}

\author{
Hertati Mukadimah *, Wening Sahayu \\ Universitas Negeri Yogyakarta. \\ * Corresponding Author. Email: hertatimukadimah.2019@student.uny.ac.id
}

\section{ARTICLE INFO}

\section{Article History}

Received:

2 June 2021;

Revised:

24 July 2021;

Accepted:

11 November 2021;

Available online:

22 November 2021

\section{Keywords}

Content and Language

Integrated Learning

(CLIL);

English for Specific

Purposes (ESP);

Vocational high

schools

\begin{abstract}
English is agreed upon as the standard language of communication throughout the world, including Indonesia. With this, teaching and learning English should be an integral part of the national education system in Indonesia because of the importance of English globally. One of the curricula in Indonesia that focuses on teaching English for Vocational High Schools (VHS) is English for Specific Purposes (ESP), where students learn English according to their needs and fields of interest. With the existence of this ESP as well as a variety of teaching methods and approaches, there is one approach that is considered truly effective in teaching this ESP program, namely the Content and Language Integrated Learning (CLIL) approach. This study aims to explore a set of literature to clarify the CLIL approach and determine if the evidence shows benefits in implementing the approach into the English for Specific Purposes (ESP) curriculum. The paper took a literature review approach and explored ten articles selected with specific criteria of being published within 2014-2020. The literature shows that the implementation of CLIL does have a positive output toward the teaching and learning process, especially for those who take English for specific purposes, such as in vocational high schools. The approach improves the linguistics aspects and the non-linguistic aspect or the students' soft skills, such as high order thinking skills, problem-solving, enhanced communication, intercultural awareness, and motivation in learning. However, to meet the success of the implementation of CLIL in the ESP curriculum, some considerations and special requirements are needed. The two distinctive preparation are the syllabus for the curriculum and the readiness of human resources; the teachers. Before applying the CLIL, the two factors mentioned need mechanisms that will support the success of CLIL for the ESP curriculum in vocational high schools. The writer proposes a model to be implemented if the curriculum for vocational high schools is going to apply CLIL. Yet, it needs more researches in the future to make sure whether the model works well or needs more improvements.
\end{abstract}

This is an open access article under the $\underline{\mathrm{CC}-\mathrm{BY}-\mathrm{SA}}$ license.

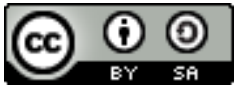

How to cite:

Mukadimah, H., \& Sahayu, W. (2021). Embedding Content and Language Integrated Learning (CLIL) into English for specific purposes curriculum for vocational high school. Jurnal Pendidikan Vokasi,

11(2), 204-212. https://doi.org/10.21831/jpv.v11i2.41065

\section{INTRODUCTION}

Content and Language Integrated Learning (CLIL) defines as a learning approach that combines language and content approaches, where a second or foreign language is not only used as a language in instructional instruction but also as a very important tool for building knowledge; such as teaching English For Specific Purpose (ESP) which focuses on certain areas, both content, and language. With the special ESP curriculum, we know that the application of CLIL using English as the language of instruction in learning is not the same from one place to another. In countries that make English one of the foreign languages to be taught and studied, such as in Indonesia, then the 
level of application of CLIL will be different from other countries that make English the main language or as a second language.

The English language has been agreed as the standard medium of communication all over the world, including Indonesia. English teaching and learning have become an integral part of an educational system for seeing the importance of English globally. It is stated by Brown (2001) that English is widely used as a tool for international communication in many fields such as transportation, commerce, banking, tourism, technology, diplomacy, and scientific research. In addition, Lauder (in Mappiasse \& Sihes, 2014) stated that English is being used to follow technological and scientific improvements and better job opportunities. From both statements, we could see that people learn English not only for having appropriate communication but also for having good skills in English would be useful to apply for work.

In order to prepare the readiness of human resources in Indonesia to cope up with the situations mentioned, the government via Law of the Republic of Indonesia Number 20 of 2003 explains the kinds of secondary level into; Sekolah Menengah Atas (SMA), Madrasah Aliyah (MA), Sekolah Menengah Kejuruan (SMK), Madrasah Aliyah Kejuruan (MAK) and other equivalent forms of education. Generally, we could divide it into two forms; Senior High Schools (SHSs) and Vocational High Schools (VHSs). What is the impact of that division in the English teaching and learning process? Each school has a different aim when it comes to the output of the students. Margana and Widyantoro (2017) stated that students of senior high schools have different orientations and expectations from the students of vocational high schools.

They further explain that the English textbooks for students of SHSs are designed by putting an emphasis on English for academic purposes since they are expected to proceed with their study at a high level, such as universities or colleges. Meanwhile, students of VHSs should be oriented to the development of English for specific purposes since they are projected to learn different fields according to their study programs to meet the expectation to become skillful workers in reference to their fields. According to Yoto and Widiyanti (in Hermanto et al., 2019), the objectives of vocational education are to prepare students to enter the workforce, choose a career, build competencies, and equip useful experiences in the workforce. Here we could see that the aim of the vocational high school is to create outcomes that are ready and skillful enough to work right away after graduating from school.

Rapid globalization in this era forces the government to prepare Indonesian citizens to have competitive skills to compete with global citizens. Instructor of the President of the Republic of Indonesia Number 9 of 2016 gives a framework on what kind of challenges will be encountered by VHSs in Indonesia. The first is revolution 4.0, where everything will be cyber-based that will force the way of human life, work, and communication. The second challenge emerges as the ASEAN Economic Community (AEC) result started from the end of 2015. It means that Indonesian citizens will not only compete among other Indonesians but also with citizens around ASEAN.

There are two points of view regarding this; it is an opportunity, yet at the same time, it is also a threat. It is an opportunity if the government is able to prepare the citizens with the skills needed, but it is a threat if they fail to give good provision for the citizens since they need to compete with manpower from other countries. The next challenge is the preparation for the golden generation by 2045 as a means of demography bonus. The last challenge which occurs these days is the emergence of the millennial generation with excellent characteristics such as being smart, fast learners, and actively engaged in social media. This generation is expecting flexibility in work and the freedom to work from everywhere, every time, and everybody. The skills needed to meet those challenges are not only hard skills but also soft skills requiring a lot of practice. Thus, it needs special preparation if the outcomes of vocational high schools are going to meet the needs in their workforce or career.

The emerging challenges that involve global competition coerce the educational system in Indonesia to cope with the situation. In addition to having good skills related to the field the students learn, they also need to improve their English competence for a better job opportunity and higher achievement in the work realm. Since they are going to face international competitors, English becomes one of the compulsory requirements to bridge the differences in language. Unfortunately, many learners in Indonesia think that English is the most difficult subject, even more, difficult than mathematics, physics, economics, etc. (Panggabean, 2015). 
This kind of hardship is understandable since English in Indonesia is categorized as a foreign language (EFL), which means English is not widely used in daily life. As Vavelyuk (2015) stated, a foreign language can result in significant difficulties if a student has a low level of English, which is often the case in many non-English speaking countries. In nature, it is better to acquire all the language skills needed when learning English, nevertheless according to Nababan (in Dewi, 2015), in the EFL situation, the teaching of English is commonly aimed at mastering 'a restricted variety of English' which means it seems acceptable and reasonable to apply ESP (English for Specific Purposes) dealing with students' purposes in learning English at VHS that provides the specific area of competence (Dewi, 2015).

English for Specific Purposes (ESP) is quite distinctive to General English (GE). An ESP course is developed based on an assessment of purposes and needs and the activities for which English is needed (Rahman, 2014). According to Richards and Schmidt (in Margana \& Widyantoro, 2017), ESP is defined as a language course or program of pedagogical practices that consist of the course's content areas and objectives with regard to the fixed specific need of a particular group of learners. Panggabean (2015) shared his view toward the relation between ESP and grammar. Panggabean (2015) stated that ESP covers various fields with different objects. However, not all English instructions for specific purposes should be approached with strict grammar. It means that the key point of English in the ESP context is by using the language, not teaching the language. By doing this, the learners are expected to gain English in a natural environment and could improve their qualifications related to the field they are taking.

From the definitions given by some experts above, it could be concluded that ESP creates a course in which English is used for relevant needs or purposes. It means that we need an approach that could embody the success of the implementation of ESP for VHSs students. Here, the writer proposes CLIL (Content and Language Integrated Learning), where Coyle et al. (in Vavelyuk, 2015) explain as the curriculum subject is taught in the non-native language, often English, with the emphasis depending on a situation. Many countries demand CLIL since it can reach two educational purposes in one step (Pipit, 2018). It accelerates students' ability both in a certain subject and the language itself. Thus, CLIL could be used as an alternative approach to nowadays curriculum for VHSs in Indonesia since it would boost the student's competence in a target language in a naturalistic environment.

\section{RESEARCH METHOD}

The study used integrative literature review methods by selecting a set of literature with specific selection criteria based on the topic being discussed by the writer and from a specific time frame followed by an analysis of their patterns. This article will review and synthesize the Content and Language Integrated Learning (CLIL) to be embedded in the ESP curriculum for vocational high schools. The criteria applied in selecting the literature are aimed at collecting recent and relevant research into the implementation of CLIL in the ESP Curriculum. The selected studies must have primary goals on supporting, showing benefits, and challenges toward the implementation of CLIL in the ESP curriculum. The time frame for the literature is seven years maximum.

To be specific, the criteria for selecting the literature that the author uses in this paper include several things, all of which must be met to be literate in this paper. The literature included in this research should be about CLIL, ESP, English language teaching, especially in vocational high schools, where the literature has been published in trusted journals between 2013-2020. The literature in this paper is more focused on case studies; it can be about a review of methods, challenges, and curriculum development related to the topic of discussion. After sorting and selecting literature for this paper from various sources on the internet, including Google Scholar and ResearchGate; The author gets ten articles or literature that meet the author's criteria. All of the literature and authors of this literature are from various countries, all of which focus on topics related to CLIL. 


\section{RESULT AND DISCUSSION}

\section{CLIL as an Alternative Approach for VHSs}

That English is now used as an international language. There is a rapid growth in the users of the language all over the world. There are some factors proposed by Lestari and Setiyawan (2020) on why English is now a global language. The first factor is the diaspora of the British population to other regions. She gave an example of the migration of English to the Australian population that makes English mutate and adapt to the socio-cultural context there. The second factor is related to the history of British colonization to almost 193 countries all over the world. The differences in geographical, gender, class and social group, and age create dialects of English that may differ in the form of pronunciation, grammar, vocabulary, or other aspects of language.

The increasing numbers of non-native speakers of English raise a new challenge where many language scholars are now concerned about the world Englishes and believe that it is not possible to provide a clear definition for Standard English (Rashidi \& Meihami, 2016). Kachru (in Rashidi \& Meihami, 2016) proposes three concentric circles; inner, outer, and expanding (Figure 1).

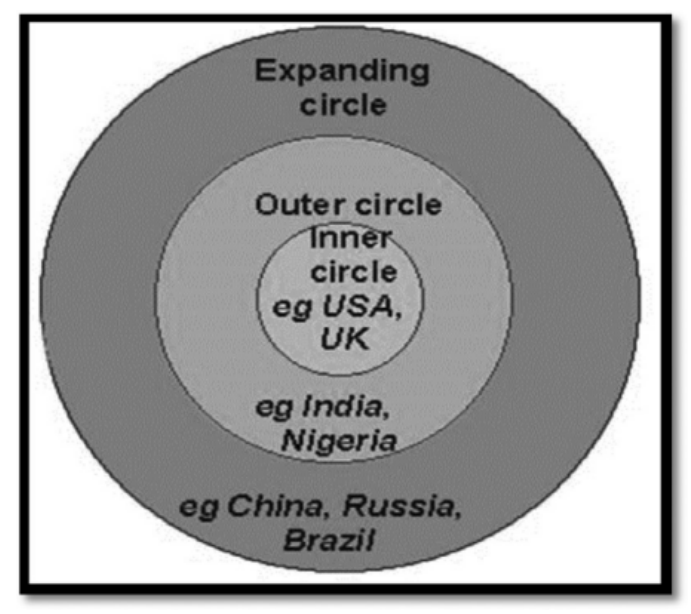

Figure 1. Kachru's Spread of English Model

The figure shows three layers; the smallest circle is the inner-circle countries in which native speakers of English are the majority of the population; for example, in the United States of America (USA) and United Kingdom (UK). The second circle shows the outer-circle countries where English has been spread through the imperial expansion of English native speaker countries. The language is used as an institutional communication tool in educational institutions, government, and others. India, Nigeria, Singapore, South Africa, etc., are examples of outer-circle countries. The outermost circle is called expanding circle, including countries that English plays limited roles, but it is starting to serve as a lingua franca for international communication 'across national and linguistic boundaries' (Rashidi \& Meihami, 2016). The consequences of English used globally emerge new communities of English users (Lestari \& Setiyawan, 2020). It is now necessary to realize that communication using English is common and natural to occur in native speakers' countries and through the rest of the world.

The phenomenon above should be considered when the government prepares the educational system to cope with current trends. It then could affect how we should provide an approach to teaching so that we could prepare our students to deal with that situation. Lestari and Setiyawan (2020) states that CLIL can be said to be a domino effect from the English global perspective. Further, they explain several things related to CLIL: First, CLIL is a trend of teaching English in the inner, outer, and expanding circle, where one of the trends is using English as a medium of instruction for non- English subjects in both private and public schools. Second, CLIL is an alternative method that applies the principles of the communicative approach where English is taught through nonEnglish lessons with the aim of making learners learn languages based on content relevant to the real 
context. Third, CLIL is a response to the existence of multilingual communities in Europe and English as lingua franca.

Content and Language Integrated Learning (CLIL) is an umbrella term referring to a dualfocused educational approach in which content courses are taught through the medium of a foreign language (Yang, 2015). Even though CLIL seems similar to bilingualism, Vázquez (2018) emphasizes that CLIL is a kind of additive bilingualism in which the main aim is to add a new language to the students' repertoire but not pursue any balanced bilingualism. Even though CLIL is using English as the medium for the teaching and learning process, it is different from bilingualism. Gracia (in Vázquez, 2018) mentions two significant differences between the bilingual approach and CLIL: 1.) The foreign language also takes the form of an individual subject in the curriculum; and 2.) There is coordination between the content and the language, the latter furnishing the necessary linguistic resources to assimilate the content. CLIL is also associated with the development of skills such as problem-solving, risk-taking, linguistic confidence, communication skills, vocabulary, selfexpression, spontaneous talk, cultural awareness, and global citizenship (Lasagabaster \& Doiz, 2017).

Those skills are needed by the students of vocational high schools when they enter the professional world since it is not only the hard skills needed but also the soft skills. Meanwhile, we could not shape soft skills in just one night. It needs continuous practice and application in daily life. The implementation of CLIL has some fundamental principles include placing students at the center of the learning cycle; teachers adapting to new forms of collaboration and coordination; an emphasis on personalized learning; the use of cross-linguistic pedagogy; and application of a comprehensive pedagogical framework which is commonly referred to as the 5c's (Pérez et al., 2018). 5c's framework is the extended version of the $4 \mathrm{c}$ framework described in Coyle (in Pérez et al., 2018). The 5c's covers; First, content which includes teaching and learning focused on content where the specific content taken from learning standards and learning objectives. The second is communication which covers scaffolding of vocabulary, grammatical structures, functional and academic language. Third, Cognition means that the learning process should enhance the students' critical thinking and thinking frameworks. Fourth, Competences which covers language knowledge, planning, cooperation, learner needs, interaction, cultural awareness, evaluation, development, and subject knowledge. The fifth is community which covers local, national, and global communities.

Those principles are the basics in creating a suitable curriculum using CLIL to teach in the ESP context. CLIL is not merely using English in the teaching and learning process. Rather it enhances how to use the language to cope up with their future environment.

\section{The Benefits of Implementing CLIL}

Yang (2015) proposes that the implementation of CLIL in the teaching and learning process brings benefits both in linguistics skills and non-linguistics. CLIL learners have been found to enhance their speaking skills by producing more and longer utterances, developing constructive ability in the target language and displaying a higher language level than non-CLIL learners. While in the non-linguistics area, CLIL boosts the learners' motivation to keep learners interested in foreign language learning, and it enhances the learners' mobility, employability, and intercultural communication, preparing them for future careers.

Dalton-Puffer (Pipit, 2018) proposes four advantages of CLIL: 1.) Creates conditions for naturalistic language learning; 2.) Provides a purpose for language use in the classroom; 3.) Has a positive effect on language learning by emphasizing meaning rather than form; and 4.) Drastically increases the amount of exposure to the target language. In line with those advantages proposed by Rohmah (2019) offers the benefits of applying CLIL for learners, such as: 1.) Learners are motivated; 2.) Learners developed their cognitive and communication skills; 3.) Learners communication skills progress more due to meaningful communication; 4.) Learners receive a lot of language input and output; and 5.) Learners develop intercultural awareness.

Lestari and Setiyawan (2020) mentioned that CLIL could allegedly help students to master both language knowledge and non-language subject content taught. The study examined the English vocabulary mastery and non-language subject matter knowledge and showed good results. This may be due to the meaningful learning provided by implementing CLIL since the vocabulary learning 
provided is integrated with the lesson's content. This kind of implicit learning gives more exposure for the students and, at the same time, shows the context on how to use the vocabulary.

The results of some previous studies above display the benefits of the implementation of CLIL not only in the linguistics field in the form of improvement in using English appropriately, but also in the non- linguistics field related to soft-skills needed in the professional world, such as; improvement in the learners' mobility, employability, communication skills, and intercultural awareness which are beneficial for their future careers.

\section{The Challenges of Implementing CLIL}

The first complaint related to the use of English as a medium language for the teaching and learning process would be the language itself. English is very different from Indonesian Language in terms of phonology, morphology, and syntax (Panggabean, 2015), which can cause anxiety and lack of self-esteem to perform the language resulted in switching to their native language in peer-to-peer interactions (Yang, 2015). In order to fully implement CLIL in the Indonesian context, probably quite challenging, and it might take some time to prepare the 'perfect' program.

To deal with this kind of situation, the implementation of CLIL could modify the classification of CLIL courses proposed by Greere and Räsänen (in Arnó-Macià \& Mancho-Barés, 2015), ranging from the absence of the integration of language and content to full collaboration between language and discipline specialist as follow; First, the non-integration model (which they term 'non- CLIL), involving independent content and language courses (less than $25 \%$ exposure to English in content courses). Second, the language for specific purposes (LSP) or Discipline-Based Language Teaching mode, similar to the theme-based model (i.e., subject-matter exposure through LSP subjects). Third, the pre- CLIL model (language/content) involves LSP courses preparing for content courses (similar to the CBI adjunct model) or content courses taught through the foreign language. Fourth, the adjunct- CLIL model, which tailors language instruction to disciplinary needs, based on the collaboration of language and subject specialists, and the last, the CLIL model involves the team teaching of dual programs catering for language and content.

The dream of implementing CLIL is quite fantastic since it aims to achieve two educational purposes in one step where it accelerates students' ability both in certain subjects and the language itself. However, the teachers as the facilitators of the learning process also play big roles in determining the success of the implementation of CLIL. Unfortunately, the research conducted by Pipit (2018) found some unpleasant results regarding the teachers' English proficiency level. Many of the teachers show no effective communication during the teaching and learning process. The students argued that the teachers' pronunciation was unclear and less understanding of students' questions resulted in dissatisfying explanations related to the subject. The deficiency analysis shows the difference between desirable English competence and teachers' existing competence (Pipit, 2018). So, if the government does really want to create skillful outcomes from vocational high school, it should first prepare the readiness of human resources. It would be better if the teachers for vocational high schools take international programs when they pursue their Bachelor's degrees of the education program, which are commonly found in universities nowadays in Indonesia.

\section{How to Embed CLIL into ESP Curriculum?}

The main objective of CLIL, where it puts the context of the language used, could bring the improvement of qualifications or skills possessed by the vocational high schools students since they are projected to work immediately after they graduate. Then, how to embed this approach into the ESP curriculum for vocational high schools? Figure 2 gives an illustration of what kind of ESP course was proposed by the writer by adapting the English Medium Paradigm proposed by SchmidtUnterberger (2018).

An adequate amount of English knowledge must support the success of CLIL implementation. Thus it is necessary to give the students good provision before implementing the full English classroom. The pre-sessional CLIL could be implemented in the first semester of vocational high schools. The subjects being taught during this class are the basic knowledge of English to perform an appropriate English in their daily life, such as; introduction, asking for and giving 
information, opinion, etc. Vocabulary mastery is also needed in this phase since this is the base for their next course level.

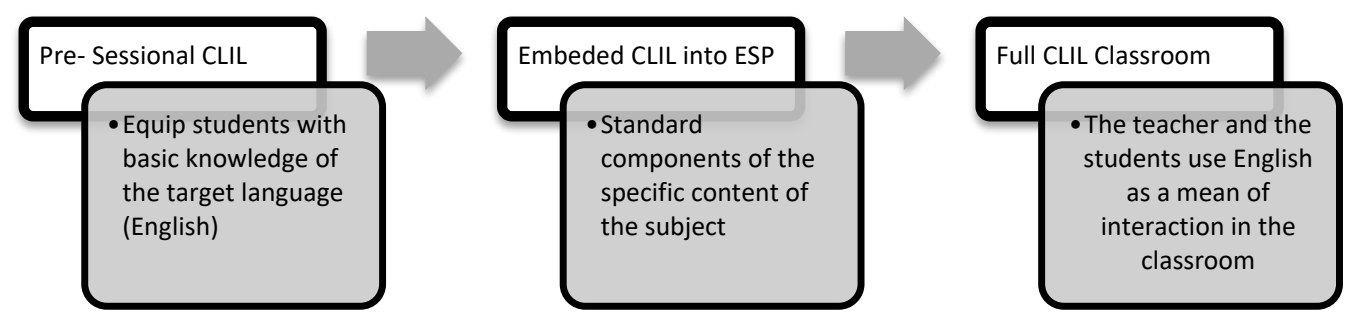

Figure 2. Embedding CLIL into ESP Curriculum

The second phase of embedding CLIL into the ESP curriculum, called Embedded CLIL into ESP, could be implemented when the students of vocational high schools are getting on their second semester. The course is designed to develop discipline-specific linguistic demands of a particular program. For example, the students majoring in Accounting are starting to get introduced to the terms used in accountant, how to prepare the presentation, present presentations, analyze trends, etc. Here, more practices are needed rather than theories. Thus, the teacher needs to play his or her role as a facilitator rather than an information-giver.

Finally, the last phase of embedding CLIL into the ESP curriculum for vocational high school is the full CLIL classroom. Starting from the third semester, the teacher and the students need to use English during the teaching and learning process fully. Create an environment where both the teacher and the students are in the real situation of using the language on the subject they are learning. As an example, in the accounting class, the teacher needs to explain the materials in (hopefully) full English, and during the classroom projects, the students also need to perform in English.

\section{CONCLUSION}

The previous discussions have shed light on how CLIL would be beneficial for the development of our educational system in Indonesia. The success of the implementation of CLIL would boost the outcomes of Vocational High Schools students so that they would be ready enough to compete with other job-seekers, not only local job-seekers but also from other countries. CLIL is believed to promote not only linguistics skills but also their soft skills since the implementation of CLIL during the learning process would create an environment where they need to employ skills such as high order thinking skills, practicing problem-solving, maintaining good communication and teamwork, and also the use of English during the learning process could enhance their confidence on using the language later in their future career.

Seeing the many advantages of applying CLIL for Vocational High Schools to prepare graduates ready to encounter the world of work, the government then needs to create a curriculum suitable for this condition. In the previous discussion, the writer has promoted a model on how to embed CLIL in the ESP curriculum. The CLIL could be applied step by step during the semesters since English in Indonesia is still considered a foreign language, so it is common to find students who are not familiar with using English appropriately. It could take some time for both teachers and students to adapt to this kind of teaching and learning environment. However, the benefits offered are quite commensurate.

Furthermore, another point to be prepared to support the success of CLIL in the ESP curriculum for Vocational High Schools is the government needs to ensure the readiness of human resources. As the key point of the implementation of CLIL, the teachers should have good skills in teaching using English for their materials. There should be different ways of recruiting the teachers for Vocational High Schools where English competence should be one of the obligatory requirements. Fortunately, there have been numerous universities with international classes for their education programs in Indonesia. 


\section{REFERENCES}

Arnó-Macià, E., \& Mancho-Barés, G. (2015). The role of content and language in Content and Language Integrated Learning (CLIL) at university: Challenges and implications for ESP. English for Specific Purposes, 37, 63-73. https://doi.org/10.1016/j.esp.2014.06.007

Brown, H. D. (2001). Teaching by principles: An interactive approach to language pedagogy (2nd ed.). Longman.

Dewi, S. U. (2015). Syllabus of vocational high school based on ESP approach. Dinamika Ilmu: Jurnal Pendidikan, 15(2), 273-295. https://doi.org/10.21093/di.v15i2.73

Hermanto, F. Y., Sutirman, S., Hidayati, B., \& Sholikah, M. (2019). The need of practical teaching in vocational high school of automation and fffice management program. Jurnal Pendidikan Vokasi, 9(3), 238-248. https://doi.org/10.21831/jpv.v9i3.26734

Lasagabaster, D., \& Doiz, A. (2017). A Longitudinal Study on the Impact of CLIL on Affective Factors. Applied Linguistics, 38(5), 688-712. https://doi.org/10.1093/applin/amv059

Lestari, S., \& Setiyawan, R. (2020). Technology era, global English, CLIL: Influence and its impact on English teaching for young learners in Indonesia. IOP Conference Series: Earth and Environmental Science, 469(1), 12094. https://doi.org/10.1088/1755-1315/469/1/012094

Mappiasse, S. S., \& Sihes, A. J. Bin. (2014). Evaluation of English as a foreign language and its curriculum in Indonesia: A review. English Language Teaching, 7(10), 113-122. https://doi.org/10.5539/elt.v7n10p113

Margana, M., \& Widyantoro, A. (2017). Developing English textbooks oriented to higher order thinking skills for students of vocational high schools in Yogyakarta. Journal of Language Teaching and Research, 8(1), 26-38. https://doi.org/10.17507/j1tr.0801.04

Panggabean, H. (2015). Problematic approach to English learning and teaching: A case in Indonesia. English Language Teaching, 8(3), 35-45. https://doi.org/10.5539/elt.v8n3p35

Pérez, W. D., Fields, D. L., \& Marsh, D. (2018). Innovations and challenges: Conceptualizing CLIL practice. Theory Into Practice, 57(3), 177-184. https://doi.org/10.1080/00405841.2018.1484037

Pipit, M. (2018). CLIL as an alternative approach for designing English course syllabus in Indonesia. The Asian ESP Journal, 14(4), 47-53. https://www.google.com/url?sa=t\&rct=j\&q=\&esrc=s\&source=web\&cd=\&ved=2ahUKEwi h4de7h670AhWkILcAHZYgDREQFnoECAIQAQ\&url=https\%3A\%2F\%2Fwww.elejourn als.com\%2Fdownload\%3Fcode\%3D5bad942144e25\&usg=AOvVaw3_vQMvlNRAMzfic5 gIaPtt

Presiden Republik Indonesia. (2003). Undang-Undang Republik Indonesia Nomor 20 Tahun 2003 tentang Sistem Pendidikan Nasional. http://simkeu.kemdikbud.go.id/index.php/peraturan1/8-uu-undang-undang/12-uu-no-20tahun-2003-tentang-sistem-pendidikan-nasional

Presiden Republik Indonesia. (2016). Instruksi Presiden Republik Indonesia Nomor 9 Tahun 2016 tentang Revitalisasi Sekolah Menengah Kejuruan dalam Rangka Peningkatan Kualitas dan Daya Saing Sumber Daya Manusia Indonesia. Presiden Republik Indonesia. https://www.google.com/url?sa=t\&rct=j\&q=\&esrc=s\&source=web\&cd=\&ved=2ahUKEwi Vwc_VhK70AhV76nMBHQlwC-

QQFnoECAgQAQ\&url=https\%3A\%2F\%2Fkemdikbud.go.id\%2Fmain\%2Ffiles\%2Fdownl oad\%2Fe451d9ec3a04121\&usg=AOvVaw2y5CboWpHtJp_TB14sDuPA

Rahman, B. (2014). Kemitraan orang tua dengan sekolah dan pengaruhnya terhadap hasil belajarr siswa. Jurnal Pendidikan Progresif, 4(2), 129-138. http://repository.lppm.unila.ac.id/213/ 
Rashidi, N., \& Meihami, H. (2016). Hidden curriculum: An analysis of cultural content of the ELT textbooks in inner, outer, and expanding circle countries. Cogent Education, 3(1), 1212455. https://doi.org/10.1080/2331186X.2016.1212455

Rohmah, I. I. T. (2019). The feasibility and effectiveness of integrating content knowledge and English competences for assessing English proficiency in CLIL. ETERNAL: English Teaching Journal, 10(1), 65-73. https://doi.org/10.26877/eternal.v10i1.3909

Schmidt-Unterberger, B. (2018). The English-medium paradigm: a conceptualisation of Englishmedium teaching in higher education. International Journal of Bilingual Education and Bilingualism, 21(5), 527-539. https://doi.org/10.1080/13670050.2018.1491949

Vavelyuk, O. (2015). To integrate successfully: Language and subject studies in ESP teaching. Procedia - Social and Behavioral Sciences, 199, 44-49. https://doi.org/10.1016/j.sbspro.2015.07.485

Vázquez, V. P. (2018). Innovations and challenges in CLIL research: Exploring the development of subject-specific literacies. Theory Into Practice, 57(3), 204-211. https://doi.org/10.1080/00405841.2018.1484035

Yang, W. (2015). Content and language integrated learning next in Asia: Evidence of learners' achievement in CLIL education from a Taiwan tertiary degree programme. International Journal of Bilingual Education and Bilingualism, 18(4), 361-382. https://doi.org/10.1080/13670050.2014.904840 